\title{
GRAPH-MATRIX MODELING OF PRODUCTION SYSTEMS AS A BASIS FOR MANAGING THE PRODUCTION CAPACITY OF METAL WORKING ENTERPRISES
}

\author{
N. V. Kireeva1, E. S. Zambrzhitskaia ${ }^{2}$, S. S. Voinov ${ }^{3}$ \\ ${ }^{1}$ Ural Social and Economical Institute, branch of Educational Institution of Trade Unions of Higher Education \\ "Academy of Labor and Social Relations" (Chelyabinsk, Russia); \\ ${ }^{2}$ Nosov Magnitogorsk State Technical University (Magnitogorsk, Russia); \\ ${ }^{3}$ Magnitogorsk Factory of Precision Products (Magnitogorsk, Russia)
}

E-mail:veo.chel@gmail.com; jenia-v@yandex.ru; mzti@yandex.ru

\section{A UTHOR'S INFO \\ N. V. Kireeva, Dr. Econ., Prof., Head of Dept. of Economics E. S. Zambrzhitskaia, \\ Cand. Econ., Associate Prof., Dept. of Economics \\ S. S. Voinov, Director}

Key words:

metal working enterprise, production capacity, production system, production link, throughput, assortment structure, "limiting" link, graph-matrix model, matrix production network.

\begin{abstract}
A B S T R A C T
Development of information systems and technologies makes it possible to use complex models for information support of management decisions. The most particular interest shows the theory of graphs and matrix calculus in order to assess the production capacity of an industrial enterprise. The study of the authors is devoted to development of methodological approaches to assessing of production capacity based on graph-matrix models. The essence of these models lies in the fact that a manufacturing enterprise is depersonalized by perceiving it as a kind of production system, consisting of production links that add up to a production chain and form a kind of production network, which is represented as a model of the production cycle. In order to perform the appropriate calculations, the specified graph model is linked to the matrix model, which takes into account the main parameters of the production system: technological connections; assortment structure of products; direct consumption coefficients; production capacity of the links. Suggested approach determines the flexibility and broad analytical capabilities of the proposed models for calculating of production capacities.

The basis for theoretical and methodological researches became the methods of analysis and synthesis, principles of consistency and complexity, graph theory and matrix calculus. The approbation of the proposed graph-matrix models of production systems was carried out using the examples of a metal working enterprise. The theoretical and practical significance of the study lies in the fact that the proposed graph-matrix model makes it possible to ensure effective management of production facilities by taking into account the mobility of the product assortment structure and complex technological links.
\end{abstract}

\section{Production capacity: conventional calculation technique and its development directions}

Production capacity is a basic operating parameter for any industrial enterprise. Calculation of production capacity for plant in general and for its separate shops gives an adequate competitive technical and economical characteristics doe an enterprise in comparison with the main market players [1-3]. Taking into account the above-mentioned principles, it is evident that the noted parameter can be considered as an independent one for management of the concrete enterprise or even management of holding structures, what is quite actual at present time. Additionally, this parameter can also be one of criteria of supplier choice procedure. In particular, the most of large metallurgical holdings purchase components and auxiliaries for metallurgical equipment via announcing electronic trading which include choice of the optimal supplier based on several criteria. Production capacity of the operating equipment is the main of these criteria. Additionally, production capacity is a key factor for determination of production potential.

According to the conventional technique, calculation of production capacity of an enterprise is based on calculation of its shops' capacities [4, 5]. Shop capacity, in its turn, is determined by capacities of technological equip- ment and machines in a shop, i.e. capacities of all shop equipment and machines are calculated. Then equipment with less throughput capacity is determined as a "bottleneck" in a shop; it characterizes the shop's production capacity [6].

It is evident that the above-described approach was efficient in the conditions of preset assortment structure of manufactured products, lack of universal equipment that is able to execute several operations corresponding to different kinds of products, as well as restriction of remedies of electronic computer tools. The problem of improvement of methodical approaches for calculation of production facilities is actively discussed at present time at the level of domestic and foreign publications. Chinese scientists who are investigating this parameter in interaction with innovation potential and company cost at a stock market, consider production capacity parameter as especially important indicator [7-11]. European researchers mostly examine the problems of management of production capacities for industrial enterprises as well as practical examples of "expanding the bottlenecks" in the concrete production system [12-16].

Especial attention is paid to publications devoted to the problems of improving the production capacity calculation technique due to use of capabilities of the modern information systems and technologies [17, 18]. In general, at present time we can speak about possibility 
of varying the methodological calculation base for production capacities, namely using matrix calculus, graph models etc. Graph-matrix models are well-known and widely used in technical and information sciences [19]. But acceptability of the a.m. methods (due to development of IT-technologies) for calculation and analysis of production capacities is principally new appearance in day-by-day work of an economist at an industrial enterprise. However, it is important to define more precisely that use of the mentioned capabilities is connected with several methodical questions, and the following material in this article will be devoted to solving these questions.

\section{Growth and analysis of production capacity based on the graph-matrix models of a production system}

Most of modern industrial enterprises, including metal processing plants, are multi-product works with flexible assortment structure. Assortment shifts are considered as one of the most important factor having the effect on the value of production capacity, and they should be taken into account in calculation technique for this parameter [20].

Graph-matrix modeling can be proposed as methodological base of the new methods for calculation of production capacity, allowing to take into account assortment shifts in the structure of manufactured products. The idea of this approach is depersonalization of an industrial enterprise based on its comprehension as any production system consisting of production links. These links make a production chain and form any production net which is presented by a graph model of production system. In order to provide corresponding calculations, the mentioned graph model is combined with a matrix model, which takes into account the main parameters of production system: technological links; assortment structure of products; direct consumption coefficients; production capacities of links. Capability of accounting the assortment shifts in the structure of manufactured products, as well as transition from "bottleneck" link to a limiting" link is a principal moment in the proposed graph-matrix model. In other words, the authors refused from calculation of production capacity of an enterprise according to the "lifting" principle, from the level of technological equipment and machines in a shop up to shop itself and then to the enterprise in general. The proposed method includes the following consequence: throughput capacities of each technological link are located in the order of increase; the link with minimal throughput capacity is determined as a "limiting" link for the production system in general.

Let's consider the essence of the proposed approach on the example of metal working enterprise.

At the initial stage of assessment of production capacity of a metal working enterprise it is required to execute description of the technological process and to present it as a graph model of production system. Technological process at the examined metal working enterprise is pre- sented by three production subsystems. Let's examine each of these subsystems with more details.

Subsystem 1: production of bushings. Manufacture of bushings at the examined plant is organized using universal metal processing equipment. It consists of the following machines: band saw, turning lathe, thermal furnace, high-precision turning lathe. It is important to note that the examined process requires charging in the furnace the batches including 24 billets, not single billets, what is expedient from the economical point of view.

Subsystem 2: production of clamps. These clamps are used for fixing metallic sheet in a rolling mill during its cutting by flying shears. These products are non-standard and are fabricated according to the drawings prepared by customers. As a rule, the most metallurgical enterprises provide purchase of these products via announcing electronic trading procedure.

The process of clamps fabrication includes mechanical production and assembling of single components. This feature is expressed in structuring the graph model of production system in the form of convergent technological process (1:1 in this case).

Realization of the production process is realized on universal metal working equipment consisting of the following main blocks: band saw and gas cutting machine; planing machine; milling machine; drilling machine. Assembling of components in the final product is conducted at the examined plant in manual mode, usually using bench tools.

Subsystem 3: production of gear couplings. This technological process is also organized at the examined plant using the park of metal working machines including band saw; thread-turning machine; slotting machine; gear milling machine; thermal furnace; high-precision turning machine.

All production subsystems of the examined plant are combined in the graph model (see fig. 1)

$$
\begin{aligned}
& r=\left(r_{j}\right)_{n * 1}-\begin{array}{l}
\text { vector of assortment relationships for } \\
\text { final products; }
\end{array} \\
& b=\left(b_{i, j}\right)_{m * n} \begin{array}{l}
\text { matrix of direct consuming coefficients } \\
\text { of products for products; }
\end{array} \\
& q=\left(q_{k, j}\right)_{l * n} \begin{array}{l}
\text { matrix of production capacity of links } \\
\text { for products. }
\end{array}
\end{aligned}
$$

In order to provide consequent calculation of production capacity, it is required to reduce all measuring units of final products to the common measure - a conditional assortment ton. Some simulated link which corresponds to each kind of finished product according to the preset assortment structure is introduced for this purpose. This simulated link is characterized by infinite production capacity and zero part of the main capital.

Let's then form the matrix model and implement consequently definition of "limiting" link of the production system. 


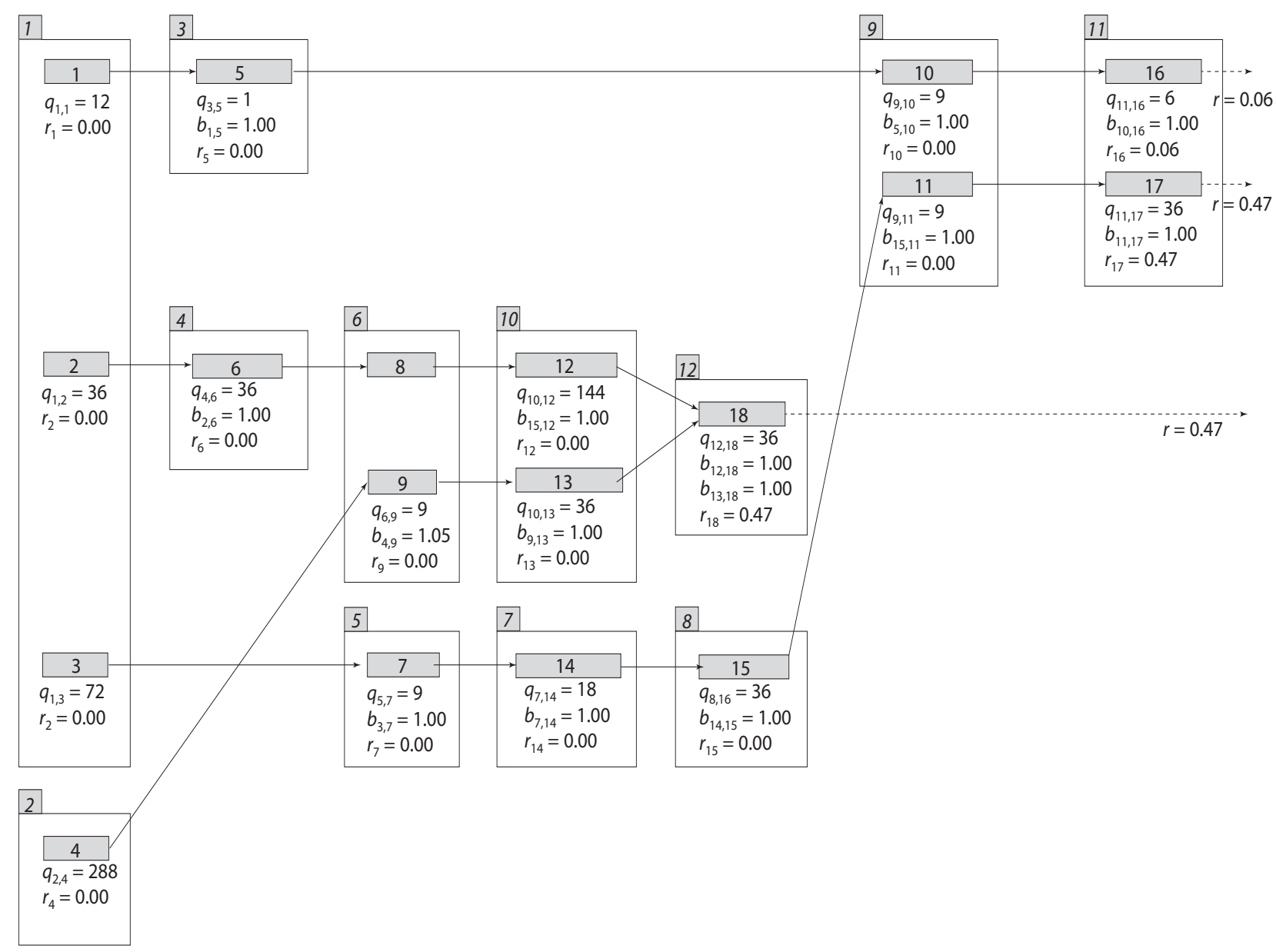

Fig. 1. Graph model of production system, production links are noted in green squares:

1 - band saw; 2 - gas cutting area; 3 - turning processing area $1 ; 4-$ planing machine; 5 - turning processing area $2 ; 6$ - milling area; 7 - slotting area; 8 - gear milling machines; 9 - heat treatment area; $10-$ drilling area; 11 - turning processing area $3 ; 12$ - assembling area

It is suggested to conduct calculation of throughput capacities of production system links on the base of a graphmatrix model in conditional assortment units (tons) in the following way:

$$
L T=\frac{1}{\frac{1}{q}(E-b)^{-1} r},
$$

where $L T$ - a vector of throughput capacity of production system links; $E$ - ordinary matrix with corresponding units.

The initial data for calculation of production capacity of the examined plant are presented in the tables $\mathbf{1}$ and $\mathbf{2}$ in matrix form.

The result of calculation of production capacities of the examined production system links is presented in the table 3 .

Then, according to the suggested algorithm, calculation of the system production capacity in general is conducted in conditional assortment units (tons), in correspondence with assortment structure of products which was preset at the initial calculation stage.

$$
C=\min _{k=1, \ldots k}\left(L T_{k}\right),
$$

where $k$ - number of production system links.
Based on the results of conducted calculations, capacity of the examined production system makes 17 conditional assortment units of products. It is important to note that not one link, several links, such as "rough" turning processing 1 as well as milling and heat treatment, are determined as "limiting" links of the analyzed production system. Thereby the measures aimed on increase of production capacity of this system should be oriented on unblocking three links, not one. It is evident that content of "limiting" links can vary with variation of assortment of manufactured products. In this connection, development of modernization and reconstruction plans for production system facilities should be accompanied by thorough research of final customers and prediction of the market assortment structure of products. The formulated task is independent from the methodical point of view and needs detailed processing at the levels of a single plant and industrial branches in general. So, use of the described technique allows to rise management efficiency for production facilities of modern industrial enterprises, particularly quality of modernization and reconstruction plans, as well to assess readiness of a plant for varying the assortment structure of products under influence of demand and supply market trends. 


\begin{tabular}{|c|c|c|c|c|c|c|c|c|c|c|c|c|c|c|c|c|c|c|}
\hline \multicolumn{10}{|l|}{ Table 1. Matrix of direct consuming coefficients of products for products $(\boldsymbol{b})$} \\
\hline & 1 & 2 & 3 & 4 & 5 & 6 & 7 & 8 & 9 & 10 & 11 & 12 & 13 & 14 & 15 & 16 & 17 & 18 \\
\hline 1 & 0 & 0 & 0 & 0 & 1 & 0 & 0 & 0 & 0 & 0 & 0 & 0 & 0 & 0 & 0 & 0 & 0 & 0 \\
\hline 2 & 0 & 0 & 0 & 0 & 0 & 1 & 0 & 0 & 0 & 0 & 0 & 0 & 0 & 0 & 0 & 0 & 0 & 0 \\
\hline 3 & 0 & 0 & 0 & 0 & 0 & 0 & 1 & 0 & 0 & 0 & 0 & 0 & 0 & 0 & 0 & 0 & 0 & 0 \\
\hline 4 & 0 & 0 & 0 & 0 & 0 & 0 & 0 & 0 & 1 & 0 & 0 & 0 & 0 & 0 & 0 & 0 & 0 & 0 \\
\hline 5 & 0 & 0 & 0 & 0 & 0 & 0 & 0 & 0 & 0 & 1 & 0 & 0 & 0 & 0 & 0 & 0 & 0 & 0 \\
\hline 6 & 0 & 0 & 0 & 0 & 0 & 0 & 0 & 1 & 0 & 0 & 0 & 0 & 0 & 0 & 0 & 0 & 0 & 0 \\
\hline 7 & 0 & 0 & 0 & 0 & 0 & 0 & 0 & 0 & 0 & 0 & 0 & 0 & 0 & 1 & 0 & 0 & 0 & 0 \\
\hline 8 & 0 & 0 & 0 & 0 & 0 & 0 & 0 & 0 & 0 & 0 & 0 & 1 & 0 & 0 & 0 & 0 & 0 & 0 \\
\hline 9 & 0 & 0 & 0 & 0 & 0 & 0 & 0 & 0 & 0 & 0 & 0 & 0 & 1 & 0 & 0 & 0 & 0 & 0 \\
\hline 10 & 0 & 0 & 0 & 0 & 0 & 0 & 0 & 0 & 0 & 0 & 0 & 0 & 0 & 0 & 0 & 1 & 0 & 0 \\
\hline 11 & 0 & 0 & 0 & 0 & 0 & 0 & 0 & 0 & 0 & 0 & 0 & 0 & 0 & 0 & 0 & 0 & 1 & 0 \\
\hline 12 & 0 & 0 & 0 & 0 & 0 & 0 & 0 & 0 & 0 & 0 & 0 & 0 & 0 & 0 & 0 & 0 & 0 & 1 \\
\hline 13 & 0 & 0 & 0 & 0 & 0 & 0 & 0 & 0 & 0 & 0 & 0 & 0 & 0 & 0 & 0 & 0 & 0 & 1 \\
\hline 14 & 0 & 0 & 0 & 0 & 0 & 0 & 0 & 0 & 0 & 0 & 0 & 0 & 0 & 0 & 1 & 0 & 0 & 0 \\
\hline 15 & 0 & 0 & 0 & 0 & 0 & 0 & 0 & 0 & 0 & 0 & 1 & 0 & 0 & 0 & 0 & 0 & 0 & 0 \\
\hline 16 & 0 & 0 & 0 & 0 & 0 & 0 & 0 & 0 & 0 & 0 & 0 & 0 & 0 & 0 & 0 & 0 & 0 & 0 \\
\hline 17 & 0 & 0 & 0 & 0 & 0 & 0 & 0 & 0 & 0 & 0 & 0 & 0 & 0 & 0 & 0 & 0 & 0 & 0 \\
\hline 18 & 0 & 0 & 0 & 0 & 0 & 0 & 0 & 0 & 0 & 0 & 0 & 0 & 0 & 0 & 0 & 0 & 0 & 0 \\
\hline
\end{tabular}

\begin{tabular}{|c|c|c|c|c|c|c|c|c|c|c|c|c|c|c|c|c|c|c|}
\hline & 1 & 2 & 3 & 4 & 5 & 6 & 7 & 8 & 9 & 10 & 11 & 12 & 13 & 14 & 15 & 16 & 17 & 18 \\
\hline 1 & 12 & 36 & 72 & 1000 & 1000 & 1000 & 1000 & 1000 & 1000 & 1000 & 1000 & 1000 & 1000 & 1000 & 1000 & 1000 & 1000 & 1000 \\
\hline 2 & 1000 & 1000 & 1000 & 288 & 1000 & 1000 & 1000 & 1000 & 1000 & 1000 & 1000 & 1000 & 1000 & 1000 & 1000 & 1000 & 1000 & 1000 \\
\hline 3 & 1000 & 1000 & 1000 & 1000 & 1 & 1000 & 1000 & 1000 & 1000 & 1000 & 1000 & 1000 & 1000 & 1000 & 1000 & 1000 & 1000 & 1000 \\
\hline 4 & 1000 & 1000 & 1000 & 1000 & 1000 & 36 & 1000 & 1000 & 1000 & 1000 & 1000 & 1000 & 1000 & 1000 & 1000 & 1000 & 1000 & 1000 \\
\hline 5 & 1000 & 1000 & 1000 & 1000 & 1000 & 1000 & 9 & 1000 & 1000 & 1000 & 1000 & 1000 & 1000 & 1000 & 1000 & 1000 & 1000 & 1000 \\
\hline 6 & 1000 & 1000 & 1000 & 1000 & 1000 & 1000 & 1000 & 72 & 9 & 1000 & 1000 & 1000 & 1000 & 1000 & 1000 & 1000 & 1000 & 1000 \\
\hline 7 & 1000 & 1000 & 1000 & 1000 & 1000 & 1000 & 1000 & 1000 & 1000 & 1000 & 1000 & 1000 & 1000 & 18 & 1000 & 1000 & 1000 & 1000 \\
\hline 8 & 1000 & 1000 & 1000 & 1000 & 1000 & 1000 & 1000 & 1000 & 1000 & 1000 & 1000 & 1000 & 1000 & 1000 & 36 & 1000 & 1000 & 1000 \\
\hline 9 & 1000 & 1000 & 1000 & 1000 & 1000 & 1000 & 1000 & 1000 & 1000 & 9 & 9 & 1000 & 1000 & 1000 & 1000 & 1000 & 1000 & 1000 \\
\hline 10 & 1000 & 1000 & 1000 & 1000 & 1000 & 1000 & 1000 & 1000 & 1000 & 1000 & 1000 & 144 & 36 & 1000 & 1000 & 1000 & 1000 & 1000 \\
\hline 11 & 1000 & 1000 & 1000 & 1000 & 1000 & 1000 & 1000 & 1000 & 1000 & 1000 & 1000 & 1000 & 1000 & 1000 & 1000 & 6 & 36 & 1000 \\
\hline 12 & 1000 & 1000 & 1000 & 1000 & 1000 & 1000 & 1000 & 1000 & 1000 & 1000 & 1000 & 1000 & 1000 & 1000 & 1000 & 1000 & 1000 & 36 \\
\hline
\end{tabular}

Table 3. Vector

of throughput capacities

of production system links

\begin{tabular}{|c|c|}
\hline 1 & 40.80 \\
\hline 2 & 612.00 \\
\hline 3 & 17.00 \\
\hline 4 & 76.50 \\
\hline 5 & 19.12 \\
\hline 6 & 17.00 \\
\hline 7 & 38.25 \\
\hline 8 & 76.50 \\
\hline 9 & 17.00 \\
\hline 10 & 61.20 \\
\hline 11 & 43.71 \\
\hline 12 & 76.50 \\
\hline
\end{tabular}

It should be mentioned that the suggested technique for calculation of a plant production capacity on the base of the graph-matrix model of a production system can be applied for any enterprise with production separated on technological stages, both during operation or designing.

It is also important to note that this technique can be used for the procedure of choosing the supplier of equipment auxiliaries, such as metallurgical (e.g. for definition of supplier of conveyor rolls etc.). It helps to evaluate sufficiency of production facilities of the producer for implementation of the concrete order in the conditions when this producer has other orders. Use of the proposed technique allows to improve substantially objectivity of the procedure of supplier choice and to decrease failure risks of deliveries due to insufficiency of production facilities.

\section{Conclusions}

This research allows to reveal possibilities of the modern IT technologies for calculation of production capacities of enterprises. Graph-matrix models that are not principally new tools by themselves and are actively used in informatics and technical sciences, should become the methodological base for the new calculation techniques of the examined parameter. The idea of a.m. models for calculation of production capacities is based 
on the approach that production plant is depersonalized via its understanding as any production system consisting of production links. These production links constitute a production chain and form a production net which can be presented as a graph model of production system. In order to provide the corresponding calculations, the described graph model is linked with a matrix model which takes into account the following main parameters of a production system: technological links; assortment structure of products; direct consuming coefficients; production capacities of links. Possibility of accounting the assortment shifts in the structure of manufactured products, as well as refuse of the "bottleneck" principle and transition to the "limiting" link concept, are the principal features of the suggested graph-matrix model.

Efficiency of the proposed graph-matrix models for calculation of production capacities was illustrated on the example of a metal working enterprise. Expedience of use of such models was proved in general and their analytical possibilities for production system management in general were displayed.

Practical approbation of the suggested technique was realized in the conditions of Magnitogorsk Factory of Precision Products. This plant used firstly this technique in 2019 in order to win electronic trading for delivery of auxiliary equipment for the large metallurgical works. The technique helped to substantiate sufficiency of production capacity reserve for realization of the tender order in comparison with other participants having other equal conditions.

The further researches should be directed on development of calculation algorithms and inclusion of these calculations in the corporate information management system of a modern industrial enterprise.

\section{REFERENCES}

1. Meporiya G. G. Efficiency of use of production capacities in machine-building. Teoriya i praktika servisa: ekonomika, sotsialnaya sphere, tekhnologiya. 2015. No. 1 (23). Available at: https://cyberleninka.ru/article/n/effektivnost-ispolzovaniyaproizvodstvennyh-moschnostey-v-mashinostroenii.

2. Semushkina E. A., Shishkarev N. I. Essence and structure of production capacities of an enterprise. Nauka i obrazovanie segodnya. 2017. No. 10 (21). Available at: https://cyberleninka. $\mathrm{ru} / \mathrm{article} / \mathrm{n} / \mathrm{suschnost-i-struktura-proizvodstvennyh-mos-}$ chnostey-predpriyatiya.

3. Kislitsyna O. A., Sherman M. S., Yamoleev R. G. Management of production capacity for achieving the strategic aims of an industrial enterprise. Rossiyskoe predprinimatelstvo. 2017. No. 11. Available at: https://cyberleninka.ru/article/n/upravlenie-proizvodstvennoy-moschnostyu-dlya-dostizheniyastrategicheskih-tseley-promyshlennogo-predpriyatiya.

4. Semushkina E. A., Shishkarev N. I. Calculation technique for production capacities of an enterprise. Nauka i obrazovanie segodnya. 2017. No. 10 (21). Available at: https://cyberleninka.ru/article/n/metodika-rascheta-proizvodstvennyh-moschnostey-predpriyatiya.
5. Pilyugina A. V., Mishchenko A. V. Models for assessment of production capacity of an enterprise. Vestnik Moskovskogo gosudarstvennogo tekhnicheskogo universiteta im. N. E. Baumana. Series "Mashinostroenie". 2017. No. 3. pp. 102-121.

6. Revutskiy R. D. Production potential of an enterprise (solutions of any applied tasks). Audit ifinansovyi analiz. 2006. No. 5. pp. 126-132.

7. Zhao T., Song Z., Li T. Effect of innovation capacity, production capacity and vertical specialization on innovation performance in China's electronic manufacturing: Analysis from the supply and demand sides. PLoS ONE. 2018. 13 (7). e0200642. DOI: 10.1371/ journal.pone. 0200642 .

8. Zhang F., Gallagher K. S. Innovation and technology transfer through global value chains: Evidence from China's PV industry. Energy Policy. 2016. 94. pp. 191-203.

9. Bi K., Huang P., Wang X. Innovation performance and influencing factors of low-carbon technological innovation under the global value chain: A case of Chinese manufacturing industry. Technological Forecasting and Social Change. 2016. 111. pp. 275-284.

10. Di Fan, Tianheng Liang, Andy C. L. Yeung, Haomin Zhang. The impact of capacity-reduction initiatives on the stock market value of Chinese manufacturing firms. International Journal of Production Economics. 2020. Vol. 223. 107533. DOI: 10.1016/j. ijpe.2019.107533.

11. Guo-liang Yang, Hirofumi Fukuyama, Yao-Yao Song. Estimating capacity utilization of Chinese manufacturing industries. Socio-Economic Planning Sciences. 2019. Vol. 67. pp. 94-110. DOI: 10.1016/j. seps.2018.10.004.

12. Lema R., Quadros R., Schmitz H. Reorganising global value chains and building innovation capabilities in Brazil and India. Research Policy. 2015. 44 (7). pp. 1376-1386.

13. Fraser K. Facilities management: The strategic selection of a maintenance system. Journal of Facilities Management. 2014. 12. pp. 18-37.DOI: 10.1108/JFM-02-2013-0010.

14. Haan J., Naubs F., Overboom M. Creative tension in a lean work environment: Implications for logistics firms and workers. International Journal of Production Economics. 2012. Vol. 137. pp. 157-164

15. Augusto de Jesus Pacheco D., Pergher I., Fernando Jung C., Scwenberg ten Caten C. Strategies for increasing productivity in production systems. Independent journal of management \& production (IJM\&P). 2014. Vol. 5. pp. 344-359.

16. Georgiadis P., Politou A. Dynamic Drum-Buffer-Rope approach for production planning and control in capacitated flow-shop manufacturing systems. Computers \& Industrial Engineering. 2013. Vol. 65. pp. 689-703.

17. Iravat Teerasoponpong, Apichat Sopadang. A simulation-optimization approach for adaptive manufacturing capacity planning in small and medium-sized enterprises. Expert Systems with Applications. 2021. Vol. 168. 114451. DOI: 10.1016/j.eswa.2020.114451.

18. Danilov G. V., Ryzhova I. G., Voynova E. S. Analysis of structure and assessment of proportionality of production capacities of an enterprise. Vestnik Magnitogorskogo gosudarstvennogo tekhnicheskogo universiteta im. G. I. Nosova. 2012. No. 1 (37). pp. 79-82.

19. Danilov G. V., Ryzhova I. G., Zambrzhitskaya E. S. Analysis of sensitivity of production capacity, zero profit point and reserve of financial stability to assortment shifts. Ekonomicheskiy analiz: teoriya i practika. 2012. No. 43 (298). pp. 18-23.

20. Danilov G. V., Voynova E. S., Ryzhova I. G. Modeling of the effect of products assortment on the main parameters of an enterprise. Ekonomicheskiy analiz: teoriya i practika. 2012. No. 15 (270). pp. 40-46. 